\title{
Using Strategy Training to Enhance Students' Reading Comprehension
}

\author{
Endang Kusrini, M. Hum \\ Muhammadiyah University of Purwokerto \\ Purwokerto, Indonesia \\ Endang kusrini@gmail.com
}

\begin{abstract}
The notion of awareness rising is central to reading instruction. These steps of teaching reading should increase students' awareness about the processes involved in reading, the students actively engage in meaning making with several steps. Moreover, the situation at university demands knowledge of reading strategies in order to be successful as learners are exposed to read some reading materials. Fyfe (1985: 11) suggests that teachers need to design reading strategy instruction that focuses on explicit instruction. He says that learners who receive strategy training generally read better than those who do not.
\end{abstract}

Key words: Strategy Training, Reading, Comprehension

\section{Introduction}

Reading is an important activity in which teachers and students have to deal with in daily academic life. Most of knowledge is obtained from written source such as books, newspapers, articles, magazine, and even online news. In this case, reading comprehension holds an important role. When students do not have good reading comprehension, they will feel reluctant to read. As a result, when they do not read, they do not get information or knowledge. For university students, most of the literatures that they need for their study are written in English. In this case, a good reading comprehension is highly required. If not, students will find it difficult to develop the theory related to their thesis or any scientific writings they make.

As Nunan (2003: 6) says, with strengthened reading skill, learners will make greater progress and development in all other areas of learning. Dechant (1991: vii) notes that reading is so interrelated with the total educational process that educational success requires successful reading. Reading is believed as a required activity in learning most of all subjects since reading has been proved in increasing student's knowledge. Reading has functions as a means to access information in the global era. It means that reading is a process of combining information from a text and reader's background knowledge to building meaning (Nunan, 2003: 7). Reading is not only used to obtain information but also a facility for learners to learn language. Reading can improve general language skills and help them think in the target language, enrich vocabulary, improve writing skill and is a good way to find out about new ideas, facts, and experiences (Milkulecky and Jeffries, 1996: 1).

Reading consists of paragraph that coherently and cohesively are connected. The paragraph contains sentences, clauses, and words. In linguistics, a word is the smallest element that can be uttered in isolation with semantic and pragmatic content (with literal or practical meaning). This contrasts deeply with a morpheme, which is the smallest unit of meaning but will not necessarily stand on its own. A word may consist of a single or several morphemes. Related to the function of reading in enriching vocabulary, when students know a word, the class of words, and morpheme, they will find it easier to learn clauses and sentences. The more vocabularies the students memorize, the easier the students learn bigger element of language. Indirectly, it will help students understand the structure of a sentence. In addition, when the students get used to reading text, they will have a lot of input of forms and structure of sentences. Thus, reading is very essential for students seen from linguistic point of view.

Among other language skills, reading is considered to a have more prominent role on academic achievement. Students with higher reading skills tend to easily get understanding on a bulk of given materials rather than those with lower reading skills (Cullinan, 2000: 10). This is consistent with Dechant's (1991: vii) claim that reading is the key to success in school, and to the personal and social adjustment. Educational success requires successful reading. Grabe (2009: 6) maintains:

"That citizen of modern societies must be good readers to be successful. Reading skills do not guarantee success for anyone, but success is much harder to come by without being a skilled reader".

Realizing the importance of reading skills, students of English Department are expected to study various reading skills since on the grounds that they are projected to teach at Senior and Junior High School where reading is the focus of the English curriculum in Indonesia. Teaching English at English Department is different from that at secondary schools in many respects: status, number of hours, instructional objectives, method of teaching, and teaching materials. 
The findings results from need analysis imply that current teaching practices of reading skills in Indonesia, need to be enhanced and an innovative reading instruction needs to be developed. Current International studies imply that Indonesian students should develop their reading skills both in their first language and in second language. They have poor reading skills and belong to the lowest rank in the world (Richard, 2015). The importance of teaching reading strategies has not been the concern of the lecturers. The lecturers emphasize more on the skill using of reading rather than the skill getting aspect.The content, sequence, and tasks of reading class need to be developed in line with the adaptation of proposed framework.

Based on the current research by Sandiarsa (2013: 78), many factors can cause students' low competency in comprehending reading text and in achieving the competencies of reading. The factors include a poor input (the students themselves), the English teacher, the materials of reading that are used, and the times consumed in teaching reading, and teaching strategies that are used in teaching reading. All of those factors will influence how well the students can achieve reading competence. Furthermore, Pressley (1995: 19) states that teacher's effective strategies will engage students and encourage them to become active readers in reading process.

Alderson (2000: 24) observes that most classroom activities engage teachers in comprehension assessment. Teachers usually design tests of particular text comprehension. This is subsequently supported by Parera (1997: 27) who claims that teachers have not invented the students to read and used textbooks as reading materials together with the students. Teachers focus on training students to answer questions rather than asking the students to read. In other words, the teachers focus most of their attention on the product of reading the comprehension, and neglect the process of comprehending.

However, this is not a problem specific to the teaching of English as foreign language in Indonesia, as Nuttal (1982:125) points out that product oriented reading instruction has been a pervasive problem throughout most EFL setting.

Cahyono and Widiati (2006:56) suggest that the future development of EFL reading instruction in Indonesia should be geared toward reading classrooms where learners become strategic EFL readers. Jansen and Stoller (1996: 256) maintain that to raise the awareness, the teacher needs to:

1. decide the strategies to be taught and emphasized in the classroom according to student's purposes, background knowledge, objectives of instruction, and the demands of the text;

2. clarify what strategies to teach and how, when and where readers can use these strategies; and

3. be flexible and willing to adapt the instruction and make strategic decision to evaluate the instruction.
The notion of awareness rising is central to reading instruction. These steps of teaching reading should increase students' awareness about the processes involved in reading, the students actively engage in meaning making with several steps. Moreover, the situation at university demands knowledge of reading strategies in order to be successful as learners are exposed to read some reading materials. Fyfe (1985: 11) suggests that teachers need to design reading strategy instruction that focuses on explicit instruction. He says that learners who receive strategy training generally read better than those who do not. His study revealed that the use of strategy did positively affect reading comprehension.

Concerning the importance of reading and those phenomena above, university students, especially English Department students are expected to have a good reading skill. Students are demanded to understand the contents of various types of texts. This paper will concern how the students can achieve the meaning from text. The use of strategy training will be significant to enhance the students' reading skill.

\section{What is reading}

\section{Literature Review}

The definition or our understanding of reading has been evaluated from the traditional view to the modern. Reading was traditionally viewed as a passive process in which the readers simply decode the written symbols without bringing their own knowledge to interact with the text (Gebhard, 1999: 197). Alderson (2002: 23) called these readers passive decoders of sequential graphic-phonemic-syntactic-semantic system. However, after the emergence of the psycholinguistic model of reading (Goodman, 1976, Smith 1971-1973), research on reading shows that reading is actually an active process, in which the reader creates meaning from the printed words. As Goodman (1976) described, reading is psycholinguistic method of reading and argued that it had provided new insights into the reading process as well as the process of learning to read. Just as we use information stored in the background knowledge to understand and interact with the world around us, so do we use knowledge to make sense of print.

Meanwhile, Grabe (1997: 377) argues that reading can be seen as an active process of comprehending where the students need to be taught strategies to read more efficiently. For example, guess from the contexts, define expectation, make interference about the text, and skim ahead to fill in the context. Grellet (1981: 3) defines reading comprehension as understanding a written text, which means extracting the required information from it as efficient as possible. Furthermore, the teacher asks the students to read the text to grab the information and understand the material. Teacher assumes that in order to comprehend the text, the students should answer some questions provided after the text. Students tend not to read a text for overall 
meaning but rather to read in a point in the text at which a cue word in a question suggests the answer may be found (MacKay, 1979: 14).

Definitions of reading appear in various perspectives, each of which is complementary; among others are comprehension, interaction of symbols, decoding, mental process, and interactive process. Primarily, reading is a means of communicating information between the writer and the reader. The reader tries to understand ideas that the writer has put in print (Vacca, Vacca\& Gove, 1991). Reading may involve decoding and comprehension process. Decoding process refers to the process of saying printed words into a representation similar to oral language either silent or aloud.

Reading is not merely sounding the written language into spoken, either orally or silently. Reading is a process of understanding written language (Rumelhart, 1985: 27). Since reading is a process, it starts from viewing the linguistic surface representation and ends with certain ideas or meaning about massage intended by writer. Thus, reading is perceptual process and cognitive process.

Based on those experts' arguments, the writer defines that reading as an active receptive skill entails the reader's efforts to comprehend print (visual information) with the help of reader's prior knowledge (non-visual information) in order that the reader's interpretation approximates to the author's intention.

\section{Teaching Reading in Higher Education}

\section{Principles of Teaching Reading}

The following principles and the ways to teach reading can guide the design and practice of a reading program (Nation, 2009: 7)

1). Meaning -Focused Input

Meaning-focused input involves getting input through listening and reading where the learners' focus is on understanding the message and where only a small proportion of language features are outside the learners' present level of proficiency. In a reading and writing program, extensive reading is likely to be major source of meaningfocused input.

a) Practice and training in reading should be done on a range of reading purposes. A reading course should cover these purposes- reading to search information (including skimming and scanning), reading to learn, reading for fun, reading to integrate information, reading to comment on texts, and reading to write.

b) Learners should be doing reading that is appropriate to their language proficiency level. This course should include reading simplified material at a range of levels, particularly extensive reading or graded reader. c) Reading should be used as a way of developing language proficiency. Learners should read with $98 \%$ coverage of the vocabulary in the text so that they can learn the remaining $2 \%$ through guessing from context.

\section{2) Meaning - Focused Output}

Meaning-focused output involves the learners producing language through speaking and writing where the learners focus is on others understanding the message. Meaning-focused output occurs when learners write essays and assignments, write letters, write a diary, send email and text messages to each other, and write about their experience. Reading should be related to other language skills. The course should involve listening, speaking, and writing activities related to the reading.

3). Language-Focused Learning

Language-focused leaning involves deliberate attention to language features both in the context of meaning-focused input and meaningfocused output and in decontextualized learning and teaching. In the reading and writing program, language-focused learning occurs in intensive reading, when learners consult dictionaries in reading and writing, when they get languagefocused feedback on their writing, when they deliberately learn new vocabulary for receptive or productive use, and when they study grammar and discourse features. There are many ways of making language-focused learning as a part of the course, but a teacher needs to be careful that this does not take up more than $25 \%$ of the total course time (Nation, 2009: 2)

a) Learners should be facilitated/assisted to develop the skills and knowledge needed for effective reading. The course should work on the sub-skills of reading and the language features needed to read, including phonemic awareness activities, phonics, spelling practice, vocabulary learning using word cards, and grammar study. Some of this can be done through intensive reading.

b) Learners should be given training and practice in a range of reading strategies. These strategies could include- previewing, setting a purpose, predicting, posing questions, connecting to background knowledge, paying attention to text structure, guessing words from context, critiquing, and reflecting on the text (Jansen and Stoller, 1998 as cited in Nation 2009)

c) Learners should be given training and practice in integrating a range of strategies. Learner should be familiar with a strategy package procedure like reciprocal teaching or concept-oriented reading.

d) Learners should become familiar with a range of text structure, such as those uses in newspaper report, stories, recounts, and information reports. 


\section{4). Fluency-Development}

Fluency development is often neglected in courses, partly because teachers and learners feel that they should always be learning something new. Fluency development involves making the best use of what is already known. The best-known kind of fluency development is speed-reading where learners focus on increasing their reading speed while still maintaining good comprehension. To make speed-reading courses to work well with learners of English as ESL/EFL, the reading material needs to be well within the learners' level of proficiency.

a) Learners should be helped and pushed to develop fluency in reading. They need to read material that is very familiar and contains no unknown language features. There should also be speed-reading practice in word recognition and in reading for understanding. These can include activities such as speed-reading, repeated reading, paired reading, scanning, and skimming.

b) Learners should enjoy reading and feel motivated to read. Learners should have access to interesting texts and be involved in activities like listening to stories, independent reading and shared reading (blown up books). Native speaking children like to read scary books, comics and cartoons, books about sports and magazines about popular culture. These are not usually found at school.

c) Learners should read a lot. This can be monitored and encouraged by extensive reading and issue log.

\section{Strategy Training in Teaching Reading}

Thegoalofstrategytrainingisforstudentstob

ecomeautonomousoneswiththewisdomtouse

strategiesappropriatelyinavariety

Inotherwords, the teachers'goalof strategytrainingistoteachhow, when, whatandwhystrat egiescanbeusedtoenhancetheirlearning (Yang Ling, 2016). Furthurmore, Yang explains thefirststepis tointroduceanddemonstratestrategies. The aimsareto enablestudentstochoosestrategiessuitedtothemselves, understandtheeffectivenessandfeasibility of certainstrategies, mastertheirconcreteoperationandthu simprove

students'competenceofapplyingstrategiescomprehens ively. Thereis a modeldesignedtoraisestudents' awarenessin using startegy,togivestudentschancestopracticethestrategi esthattheyarebeingtaught,and tohelpthemunderstand howtousethestrategiesinlearning reading,atleastsix strategiesareworth elaborating. The kinds of micro skills are developed through task and activities in the steps of pre-reading, whilst reading and post reading. The task or activities which accompany the text should have two intentions: the first is to create or maintain learners motivation; the second is to develop the useful microskills for reading. The strategy training should be accompanied by interesting tasks, in order to improve learner's motivation.

1. Predicting: It is a general technique use in the reading process (Grellet, 1981). Smith (1988) also argues that prediction was viewed as the core and the basis of reading comprehension. Nuttal (1996) explained that if a reader understands a text, he could predict with a fair chance of success what is likely to comes next and what is not. It requires the readers to use schemata about the way stories work: the way texts are constructed, and the way people tend to think. Therefore, making prediction is effective to promoting reader activation on their background knowledge, which is an important part in the process of reading.

2. Extracting main ideas. It is important to help learner look for the main ideas of a passage and to avoid getting distracted by unfamiliar vocabulary. Typical activity types which develop this skill are matching exercises; text with picture, text with heading. This only makes the reader think a bit more. In order to get the gist of it, to know how it is organized, or to get an idea of the tone or intention of the writer (Grellet, 1981).

3. Understanding text organizationIt is sometimes difficult to understand what information is important in a passage and where it should come. Text organization activities help the reader to see what belongs to a passage, and how sentences are joined together.

4. Inferring. Inferring activities draw the reader's attention to the overall atmosphere of the passage. They also help build their vocabulary. It is the process of creating a personal meaning from text. It involves a mental process of combining what is read with relevant prior knowledge (schema). The reader's unique interpretation of text is the product of this blending. Grabe (2010) stated that the writer would have implicit the information reader has to draw upon his prior knowledge or his understanding of the context to deduce the implicitely- stated information embeded in the text.

5. Dealing with unfamilier words. Smith (1971) argued that the best way to identify unfamilier word in a text was to draw inferences from the rest of the text rather than looking it up in a dictionary. This view differentiates top down processing from bottom up processing to deal with unknown words, emphasizing the reader depends on the context to interpret words.

6. Self monitoring. In order to check the students' awareness of reading strategies, an approach known as meta cognitive theory was developed in 1970's. Metacognition is knowledge about cognition. Metacognition in reading refers to reader's background knowledge of the text, their awareness of using strategy, and of the important of particular 
strategies. According to Oxford (1990) metacognitive strategy include three strategies sets: 1) centering your learning, 2) arranging and planning your learning, and 3)evaluating your learning.

Deals with Vygotsky's theory in which language is as social activity. Strategy training also relates to Halliday that language is a social process. Knowledge is transmitted in social context, through relationship, like those of parent and child, or teacher and student, or classmates, that are defined in the value system and ideology of the culture (Halliday, 1985: 5). Strategy training concerns on the importance of developing students' awareness in using reading strategies.It emphasizes that learning will be effective if the teacher explains explicitly skills that belong to students, how language operates to build a meaning within variant texts and with each linguistic sorts. The language teaching should do continuously. So, a good teacher is continuously learning.

\section{Conclusion}

The notion of awareness rising is central to reading instruction. These steps of teaching reading should increase students' awareness about the processes involved in reading, the students actively engage in meaning making with several steps. Moreover, the situation at university demands knowledge of reading strategies in order to be successful as learners are exposed to read some reading materials. Fyfe (1985: 11) suggests that teachers need to design reading strategy instruction that focuses on explicit instruction. He says that learners who receive strategy training generally read better than those who do not.

\section{References:}

Birch, Barbara M. 2002.English L2 Reading Getting to the Bottom. New Jersey: Lawrence Erlbraum Associates Publishers.

Brown, H. Douglas. 2001. Teaching by Principles: An Interactive Approach to Language Pedagogy. New York: Pearson Education.

Dechant, E. (1991). Understanding and teaching reading: an interactive model. New Jersy: Lawrence Erlbaum Associates.

Grabe, W.(2009). Reading in Second Language. New York: Cambridge University Press

Mikulecky, Betrice S. \& Linda Jeffrie. 2007. Advance Reading Power. United State of America: Longman.

Richards, Jack C. \& Richard Schimdt.2002. Longman Dictionary of Language Teaching and Applied Linguistics. Malaysia: Frakenham Photosetting, Ltd.

Ruddle, Martha Rapp. 2005. Teaching Content Reading and Writing. United State of America: John Wiley \& Sons, Inc.

Spratt, Mary and friends. 2005. The TKT: Teaching Knowledge Test Course. United Kingdom: Cambridge University Press. 